\title{
GIOVANNI BATTISTA COCCIOLA'S ACTIVITY IN THE POLISH-LITHUANIAN COMMONWEALTH AND HIS CONCERTO AVE MUNDI SPES MARIA FROM THE PARNASSUS MUSICUS FERDINANDAEUS
}

\author{
ALEKSANDRA PATALAS \\ Uniwersytet Jagielloński, Kraków
}

Izvleček: Giovanni Battista Cocciola je bil italijanski skladatelj 17. stoletja, ki je nekaj časa deloval tudi v Poljsko-litovski zvezi. Njegova glasbena zapuščina, ki se je le deloma ohranila in je v mednarodni muzikološki literaturi tako rekoč neznana, obsega motete, cerkvene koncerte, kanconete in maše. Med drugim je napisal tudi en motet za antologijo Parnassus musicus Ferdinandaeus.

Ključne besede: cerkveni koncert, Giovanni Battista Cocciola, glasba na Poljskem, glasba v Litvi, glasba 17. stoletja.

\begin{abstract}
Giovanni Battista Cocciola was one of the seventeenth-century Italian composers active for a period in the Polish-Lithuanian Commonwealth. His musical legacy, only partially preserved and unknown to the international musicological literature, comprises motets, church concertos, canzonettas and masses. Cocciola is also the author of one concerto included in the Parnassus Musicus Ferdinandaeus.

Keywords: church concerto, Giovanni Battista Cocciola, music in Poland, music in Lithuania, seventeenth-century music.
\end{abstract}

Giovanni Battista Cocciola belongs to that group of seventeenth-century Italian musicians and composers which spent part of their artistic lives in the Polish-Lithuanian Commonwealth. Cocciola's legacy remains little known in the international musicological literature; one notices the absence of his name in Italian encyclopaedias and reference books, as well as in the German Die Musik in Geschichte und Gegenwart. His music still awaits performances and recordings. So far, the main persons to have considered Cocciola's music are Alina Osostowicz-Sutkowska ${ }^{1}$ and Irena Bieńkowska. Bieńkowska has presented a summary of his life and work in her unpublished doctoral dissertation, ${ }^{2}$

1 Osostowicz-Sutkowska, “Twórczość Giovanniego Battisty Coccioli”; Osostowicz-Sutkowska, "G. B. Cocciola".

2 Bieńkowska, "Muzyka Giovanniego Battisty Coccioli”. 
in several articles, ${ }^{3}$ and especially in her critical edition of Cocciola's collected works. ${ }^{4}$ To the facts and hypotheses offered by Bieńkowska I have been able to add a few details.

Giovanni Battista Cocciola was born in Vercelli (in Piedmont). This information comes from the title page of his concertato motets from $1625 .{ }^{5}$ He must have come to the Polish-Lithuanian Commonwealth before 1606, because in that year he was in the service of the bishop of Warmia, ${ }^{6}$ Szymon Rudnicki (who held this office from 1604 to 1621). An inscription in the Alto part of the composition Tribulationes cordis mei provides information on Cocciola's employment at the court of the bishop, who was himself a lover of music: "Joan. Battistae | Gozzolae Mus.[ici] | R[everendi]s Episc[opi] Varmen[sis] | Ao. 1606." This manuscript, held by the University Library in Uppsala, ${ }^{7}$ originates from the Jesuit College of Braunsberg (today, Braniewo in the diocese of Warmia) and was probably stolen by Swedish troops during their invasion in the years 1626-1629. Cocciola's activity at the bishop's court may have been linked to the reform of liturgical singing in the Warmia diocese, which was overseen by Adam Steinhallen, a student of Annibale Stabile in Rome who was earlier associated with the Polish royal court. Steinhallen could have asked Cocciola to help him with this reform. The religious character of Rudnicki's court ${ }^{8}$ could have encouraged Cocciola to compose church music requiring a smaller number of voices. It is worth noting that in the monumental organ tablature created between 1620 and 1640 in the Cistercian monastery in Pelplin ${ }^{9}$ (likewise in Royal Prussia) there is at the very beginning of the manuscript a series of fourteen vocal religious compositions by Cocciola for two and three voices, to which a further three pieces were added later. ${ }^{10}$ It seems possible that these come from a lost collection of musical works by him, one either printed or planned for publication.

The exact year when Cocciola arrived in the Commonwealth is unknown. Irena Bieńkowska offers the plausible hypothesis that he was recruited by the court of King

3 Bieńkowska, "Ukształtowania drobnoodcinkowe"; Bieńkowska, "Polychoral Works of G. B. Coccciola"; Bieńkowska, "Religious Works of Giovanni Battista Cocciola"; Bieńkowska, "Concerti ecclesiastici".

4 Cocciola, Dzieła zebrane.

5 The contents of the title page of the Bassus partbook: "CONCENTVS | HARMONICI | ECCLESIASTICI. | Duabus, Tribus, Quatuor, \& Quinque | Vocibus. | Cum Basso Continuo ad Organum. | IOANNIS BAPTISTAE COCCIOLAE | VERCELLENSIS. | Illustrissimi Domini D. Leonis Sapihae Cancellarij Magni | Ducatus Lituaniae Musicae Magistri. | BASSVS. | ANTVERPIAE, | APVD PETRVM PHALESIVM | ad insigne Dauidis Regis | M. D. CXXV.” The unique copy belongs to the Universiteitsbibliotheek Gent, shelfmark B-Gu Res. 672(11) (RISM 00000991016406).

6 Warmia is a region in northern Poland, then part of Royal Prussia belonging to the Polish Crown. The seat of the bishops of Warmia was the castle in Lidzbark Warmiński.

7 The manuscript no. 396 (the Tenor partbook) of the Universitetsbibliothek Carolina Rediviva in Uppsala, shelfmark Utl. vok. mus. i tr. 395-396 (RISM 190008600).

8 Cf. note 6.

9 The source known as Tabulatura Pelplińska is housed in the Muzeum Diecezjalne in Pelplin. Cf. Sutkowski and Osostowicz-Sutkowska, Pelplin Tablature.

${ }^{10}$ Cf. the compositions numbered 1-17 in the list of Cocciola's compositions inscribed in the Pelplin tablature. Cocciola, Dzieła zebrane, 16-17. 
Sigismund III Vasa at the end of the sixteenth century, when an intensive reorganization of the royal music chapel took place. As Archduke Ferdinand also did in Graz, Sigismund III sought to Italianise his musical ensemble. In 1595 many Italian musicians appeared in Poland, among them Luca Marenzio in the role of choirmaster, followed by Giulio Cesare Gabussi and Asprilio Pacelli (the last-named musician spent a long period of time in Poland - from 1602 until his death in 1623). Regarding Cocciola, in the account books of the Polish royal court for February 1598 and September 1599 one finds the names of an alto singer named Johannes Baptista, and a castrato named Andreas. Bieńkowska ${ }^{11}$ tentatively identifies the two singers with Giovanni Battista Cocciola and Giovanni Andrea Cocciola - the latter being a soprano at the court in Graz during the years 1603-1615. Giovanni Andrea likewise came from Vercelli and was a relative, maybe a brother, of Giovanni Battista. Bishop Rudnicki maintained close contact with the Polish royal court, which could have facilitated Cocciola's connection with Warmia.

Before the year 1613 Giovanni Battista Cocciola published in Gdańsk a collection of canzonettas, probably for two and three voices. The source of this information is an inventory of books drawn up after the death of the bookseller Jacob Mertzenich, who was active in Cracow during the years 1610-1613. ${ }^{12}$ One of the books Mertzenich had in stock was catalogued as "Canzonetti [sic] Cocciola duo volumina in $4^{\text {to }}$ Gedani", which denotes a pair of partbooks printed in quarto format by an unknown Gdańsk printing house. One should remember that at the turn of the sixteenth and seventeenth centuries the first demonstration of compositional skill was often the publication of a set of madrigals or canzonettas. We may suppose that the lost edition mentioned above was the formal initiation of Cocciola's career as a composer. The fact of its publication in Gdańsk (in Royal Prussia) may be associated with Cocciola's activity in that area, although the secular nature of the compositions suggests that they were connected with the environment of the royal chapel of Sigismund III rather than with the court of Bishop Rudnicki.

Before 1619 Cocciola had apparently committed to print a collection of smallscale motets, which are mentioned by Michael Praetorius in his Syntagma Musicum. ${ }^{13}$ When Praetorius discusses - among other things - the meanings of the terms motet and concerto, which are applied interchangeably, he gives examples of their use by various authors, and - most intriguingly - mentions Cocciola as a member of a group of composers who have written pieces for a small number of voices (from one to five) and called these "Motetti". Today we do not know of any publication of this kind by Cocciola. Of course, any such collection must have been issued no later than 1619. It seems likely that Praetorius was referring to Cocciola's lost collection of small-scale motets inscribed in the organ tablature from Pelplin.

In the same year, 1619, a catalogue of the publishing house of Alessandro Vincenti

${ }^{11}$ Warsaw, Archiwum Główne Akt Dawnych, shelfmark ASK I, 296, fol. 79r. See Cocciola, Dzieła zebrane, 11.

${ }^{12}$ Mertzenich's inventory is part of a larger manuscript preserved in the National Archives in Cracow, Department III (in Polish: Archiwum Narodowe, Oddział III), where it is catalogued as Acta Advocatialia Cracoviensis no. 235, fols. 1534-1593.

${ }^{13}$ Praetorius, Syntagma Musicum, 7. 
was printed. In the section numbered XII, consisting of "Messe a più voci con il basso per sonar", there is mention of "Messa, motetti Cociola à 8". ${ }^{14}$ This information was inaccurately recorded in the late eighteenth century by Ernst Ludwig Gerber, who stated that already in 1612 Cocciola had published in Venice one motet and an eight-voice mass with basso continuo in quarto format. ${ }^{15}$ The date given by Gerber seems questionable. We can be certain only that Cocciola's collection must have been printed before 1619. No copy of this publication has come down to us. We may, however, suspect that the fourteen double-choir motets by Cocciola copied into the Pelplin organ tablature originate from the print in question. ${ }^{16}$

From at least 1623 Cocciola was a choirmaster at the court of Leon Sapieha (15571633), one of the most prominent politicians and diplomats in the Polish-Lithuanian Commonwealth. This man established the power of the Sapieha family and brought it into the political elite of the Grand Duchy of Lithuania. From the end of the sixteenth century Sapieha maintained a private musical ensemble with over twenty members. In 1589 he received the title of Chancellor of the Grand Duchy of Lithuania. Published in 1625, Cocciola's collection of concertato motets entitled Concentus Harmonici is connected with Sapieha in his post of Chancellor. However, already in February 1623 Sapieha was raised to the even higher position of Palatine of Vilnius, and in July 1625 he became the Grand Hetman of Lithuania. All these circumstances allow us to believe that Cocciola must have started working for Sapieha and initiated the preparation of the collection before February 1623. ${ }^{17}$ Bieńkowska suspects that Cocciola joined Sapieha's court around $1612 .^{18}$ The collection of 1625 contains 20 compositions for a small number of voices (from one to five) plus organ. The title page describes the author as chapel master of the most illustrious Lord Leon Sapieha, Chancellor of the Grand Duchy of Lithuania. ${ }^{19}$ The print originated from the publishing house of Pierre Phalèse in Antwerp. It is worth noting that the composers working in the Commonwealth rarely published their music there because of the underdeveloped state of music printing. If any of them was fortunate enough to find a patron willing to finance the publication, it was entrusted to a printer either in Italy (Venice or Rome) or in the Netherlands, as in Cocciola's case. The Concentus Harmonici collection was offered for sale at the Frankfurt Book Fair in the autumn of 1625 and also in the spring of $1626 .^{20}$

For the period when the Parnassus Musicus Ferdinandaeus was being prepared

${ }^{14}$ Vincenti, Indice di tutte le opere, 11.

${ }^{15}$ Gerber, Historisch-Biographisches Lexikon, 291: “Cocciola (Gio. Battista) ein berühmter Komponist des vorigen Jahrhunderts aus Vercelli in Savoyen, war Kapellmeister des Lithauischen[sic] Canzlers Leonis Sapieha und lie $\beta$ im J. 1612 zu Venedig eine Motette nebst einer 8 stimmigen Missa cum B. C. in 4 drucken. Auch findet man in des Bergameno Parnasso music. verschiedene Motetten von seiner Arbeit."

${ }^{16}$ The list of the compositions (no. 18-31) in Cocciola, Dzieła zebrane, 16-17.

${ }^{17}$ As Barbara Przybyszewska-Jarmińska states, the first edition of this collection was published already in 1621 (cf. her article in the present volume of De musica disserenda).

${ }^{18}$ Cocciola, Dzieła zebrane, 12.

${ }^{19}$ Cf. note 5.

${ }^{20}$ Göhler, "Die Messkataloge”, 37. 
there is no certain information about Cocciola's activities. Perhaps he was already in the service of Sapieha in Vilnius. Maybe he attempted to obtain a position at the court of Archduke Ferdinand in Graz. He could have counted on the mediation of Giovanni Andrea Cocciola, at that time still in archducal service. Or perhaps he sought financial support from Archduke Ferdinand for a further publication? In the first quarter of the seventeenth century a nucleus of talented Italian composers - Asprilio Pacelli, Giovanni Valentini and later Tarquinio Merula - worked in the royal chapel of Sigismund III. Perhaps in this environment Cocciola did not come up to scratch, and he had to settle for work in less prestigious ensembles, such as those in the chapels of bishop Rudnicki or Leon Sapieha. Hence, perhaps, his efforts to secure a post in Graz, where, however, it was equally difficult to find rewarding employment. In 1616, after thirteen years of service, the castrato Giovanni Andrea Cocciola quitted his post and made plans to return to Italy. The reason was stated to be his poor health and the unsatisfactory financial conditions. There is no more information on Giovanni Battista Cocciola's subsequent musical career. The date and place of his death remain unknown.

Cocciola's compositional achievements centre on four musical genres: canzonettas, polychoral motets, masses and small-scale concertato motets (see table 1). Cocciola devoted most effort to the composition of concerti ecclesiastici for a small number of voices, a genre that corresponded perfectly to the needs of typical ensembles of that time. It was also this kind of work that was published in the anthology Parnassus Musicus Ferdinandaeus. Although it is known that concertato motets - still harking back strongly to the polyphonic motet style - were being composed in Poland around 1610, the number of surviving sources for this type of music is very small (some compositions by Mikołaj Zieleński and one by Asprilio Pacelli fall into this category). Against this background Cocciola's compositions form a large and important group. They give the opportunity to observe, how - gradually - the Renaissance motet was replaced by compositions of newer type.

In the two printed anthologies (of 1615 and 1627) we find two fully preserved threepart concerti ecclesiastici with basso continuo. Twenty pieces, at present incomplete (only the Basso part has come down to us), were published in 1625 (probably with a first edition in 1621) under the title of Concentus Harmonici Ecclesiastici. Around 1700 the same print formed part of the famous Ballard collection. From its description we learn that it consisted of five partbooks in quarto format. ${ }^{21}$

Among the manuscript sources of Cocciola's music the most important place is occupied by the great organ tablature from Pelplin. As I mentioned earlier, this tablature contains his seventeen small-scale concertato motets, the first fourteen of which were inscribed in an uninterrupted sequence at the start of the manuscript. They are ordered according to the number of voices. First come the pieces for two voices, then the three-part compositions. An analysis of the Pelplin tablature establishes that its principal copyist drew upon printed music available to him in order to form the collection. ${ }^{22}$ Accordingly, he sometimes copied a largish number of works by the same author. The ordering of

${ }^{21}$ Guillo, "La bibliothèque de musique des Ballard", 209-210.

${ }^{22}$ Cf., for example, Patalas, "Asprilio Pacelli in Poland". 
Cocciola's works in the manuscript suggests that he simply copied them directly from a print that today is missing, and which I would identify with the one to which Praetorius referred in 1619. So this collection, assembled before 1619, could have contained works for two, three and four voices with basso continuo.

\section{Table 1}

Giovanni Battista Cocciola's compositions (according to their musical genres)

\begin{tabular}{|l|l|l|}
\hline canzonette & Canzonette [2-3 voices?], ed. before 1613 & $\begin{array}{l}\text { Lost print, mentioned in Mertzenich's } \\
\text { inventory }\end{array}$ \\
\hline $\begin{array}{l}\text { Motets (14) for } 2 \\
\text { choruses }\end{array}$ & $\begin{array}{l}\text { In mss: } \\
\text { - Pelplin organ tablature (PL-PE) } \\
\text { - Oliwa organ tablature (Lt-Va) }\end{array}$ & $\begin{array}{l}\text { Pieces coming probably from a lost collection } \\
\text { printed in Venice before 1619 } \\
\text { (cf. Alessandro Vincenti's catalogue of 1619) }\end{array}$ \\
\hline Mass & $\begin{array}{l}\text { Missa Defunctorum a 4 } \\
\text { (ms. in D-B 40073) }\end{array}$ & Only 1 voice-part preserved \\
\hline $\begin{array}{l}\text { Church concertos (43) } \\
\text { for 2-5 voices and organ }\end{array}$ & See table 2 & \\
\hline
\end{tabular}

Cocciola's known musical legacy belonging to the genre of the concertato motet comprises forty-three pieces preserved in manuscripts and prints (see table 2).

Table 2

Cocciola's church concertos (43), for 2-5 voices and organ

\begin{tabular}{|c|c|}
\hline \multicolumn{2}{|r|}{ in print (22): } \\
\hline $\begin{array}{l}\text { One piece in the Parnassus Musicus } \\
\text { Ferdinandaeus (1615) }\end{array}$ & No known concordances in mss \\
\hline $\begin{array}{l}20 \text { pieces in Concentus Harmonici Ecclesiastici, } \\
2-5 \text { voices, organ, Antwerp, P. Phalesius, } 1625\end{array}$ & Incomplete (Basso only) (B-Gu) \\
\hline One piece in Donfried's anthology (1627) & No known concordances in mss \\
\hline \multicolumn{2}{|r|}{ in manuscript (21): } \\
\hline 17 pieces in the Pelplin organ tablatures (PL-PE) & $\begin{array}{l}\text { Incomplete; probably from the lost edition for } 2-4 \text { voices printed } \\
\text { before } 1619 \text {. }\end{array}$ \\
\hline One piece in Uppsala (S-Uu) & Incomplete; dated 1606; no known concordances \\
\hline 14 pieces in PL-Kj 40063 & $\begin{array}{l}\text { Incomplete (Basso continuo only): } \\
\text { - } 8 \text { pieces = the Pelplin organ tablature } \\
\text { - } 3 \text { pieces = } 1625 \text { print } \\
\text { - } 3 \text { pieces: no known concordances }\end{array}$ \\
\hline Four pieces in the Oliwa organ tablature (Lt-Bn) & $\begin{array}{l}\text { Incomplete } \\
=\text { the same } 4 \text { pieces as in the Pelplin organ tablature (PL-PE) } \\
\text { - probably from the lost edition for } 2-4 \text { voices printed before } 1619\end{array}$ \\
\hline One piece in Bardejov (H-Bn) & $\begin{array}{l}\text { Incomplete } \\
=\text { the same piece as in the Pelplin organ tablature }\end{array}$ \\
\hline
\end{tabular}

The Pelplin intabulations of Cocciola's concertato motets constitute incomplete testimonies. The copyist wrote down only the vocal parts, although - of course - on their basis any organist could have created an appropriate accompaniment. The existence of an original organ part is confirmed by a manuscript copy (shelfmark 40063) held by the Jagiellonian 
Library in Cracow. This is a continuo partbook containing a couple of hundred compositions by various authors, including fourteen by Cocciola. As many as eight of these have concordances in the Pelplin tablature, while three others correspond to works contained in Cocciola's print of 1625 . The continuo part fits perfectly the vocal parts inscribed in the tablature. The need for an organ accompaniment is clearly apparent when we examine the texture of certain compositions, such as, for example, Tibi laus, tibi gloria (see Figure 1). The instrumental basso often doubles its vocal counterpart, but it sometimes becomes an independent instrumental accompaniment resembling Viadana's continuo parts.

Only two printed concerti ecclesiastici by Cocciola are preserved in complete form. One is an Ave mundi spes Maria from the Parnassus Musicus Ferdinandaeus anthology. ${ }^{23}$ This composition calls for three vocal parts ("due canti e basso") plus organ, a combination very typical for the time as well as for Cocciola himself. Ave mundi spes Maria shares most of the features of his other concertato motets, which form a fairly homogeneous group. In that composition one can still observe strong links to motet-like techniques characterized, among other things, by the equal status of the voices, the use in them of imitation alongside frequent parallel motion and the presence of rather long melodic phrases. On the other hand, however, the piece is distinguished by the use of quite bold contrasts of setting and texture, obtained through the abundant deployment of concertato technique, as well as by alert, but not over-radical, subordination of the music to the words. Its strophic text is taken from a medieval sequence addressed to the Virgin Mary (see table 3). This begins with praise of the Mother of God as benevolent, radiating hope and goodness. The second stanza refers to Christ and the Virgin's care for him. The third stanza is a plea to Mary as a ruler able to comfort any believer, even one immersed in sin. The text is marked by interesting changes of affect. One way in which the composer mirrors those changes occurs on the level of modality. In the last stanza he introduces the notes $\mathrm{B}$ and $\mathrm{C}$ sharp which lie outside the principal G-Hypodorian mode, as well as clausulae peregrine leading to $\mathrm{A}$ and $\mathrm{E}$, which result in commixtio tonorum.

Table 3

G. B. Cocciola, Formal features of Ave mundi spes Maria (line of the text / number of syllables in the line / scoring / tonal destination)

\begin{tabular}{|l|c|l|l|}
\hline Ave mundi spes Maria & $8 \mathrm{a}$ & C I & clausula finalis: G \\
\hline Ave mitis, ave pia & $8 \mathrm{a}$ & C II - C II+B & clausula G - cadentia D \\
\hline Ave plena gratia & $7 \mathrm{a}$ & tutti & pause on F \\
\hline Omnis boni copia. & $7 \mathrm{a}$ & tutti & cadentia G \\
\hline & & & \\
\hline Ave virgo Mater Christi & $8 \mathrm{~b}$ & C II+B & pause on F \\
\hline tu quae sola meruisti & $8 \mathrm{~b}$ & C I & cadentia D \\
\hline esse Mater sine vero & $8 \mathrm{c}$ & tutti & cadentia G \\
\hline et lactare more miro. & $8 \mathrm{c}$ & tutti & cadentia D \\
\hline & & & \\
\hline Angelorum imperatrix & $8 \mathrm{~d}$ & tutti & pause on D \\
\hline
\end{tabular}

${ }^{23}$ Cf. Antonicek, Parnassus musicus Ferdinandeus. 


\begin{tabular}{|l|c|l|l|}
\hline peccatorum consolatrix & $8 \mathrm{~d}$ & tutti & cadentia B flat \\
\hline consolare me lugentem & $8 \mathrm{e}$ & $\mathrm{C}$ I+C II & clausula in mi to a \\
\hline in peccatis iam faetentem & $8 \mathrm{e}$ & $\mathrm{C} \mathrm{I}+\mathrm{B}$ & pause on A \\
\hline consolare me lugentem & $8 \mathrm{e}$ & $\mathrm{C}$ II & clausula in mi to e \\
\hline in peccatis iam faetentem. & $8 \mathrm{e}$ & tutti & cadentia A - peregrina, then D and G \\
\hline
\end{tabular}

Changes in the scoring and texture, which occur after each verse, bring into relief not only the structure of the text but also its meaning. This is aurally evident from the very start of the piece. Cocciola makes great use of word-painting, such as for the exclamations employing the repeated word "Ave", which appear in the two Canto voices in echo fashion. For "ave plena [...] omnis bonitas" (bar 7) all the voices appear together. At "tu quae sola" (b. 15) Cocciola introduces a short solo for Canto I alone. It is easy to discover textually illustrative rhetorical figures such as a kathabasis for the words "in peccatis" and a saltus duriusculus for "consolare".

Although the expressive means used by Cocciola in Ave mundi spes Maria are not avant-garde, they evidence his general knowledge of the concept of musica moderna. Even if his European career was rather brief and circumscribed Cocciola played an important role in the process of transplantation of the Italian idea of the church concerto into the territory of the Commonwealth.

\section{Music example}

Giovanni Battista Cocciola, Tibi laus, tibi gloria, from the Peplin tablature (transcription by Aleksandra Patalas)

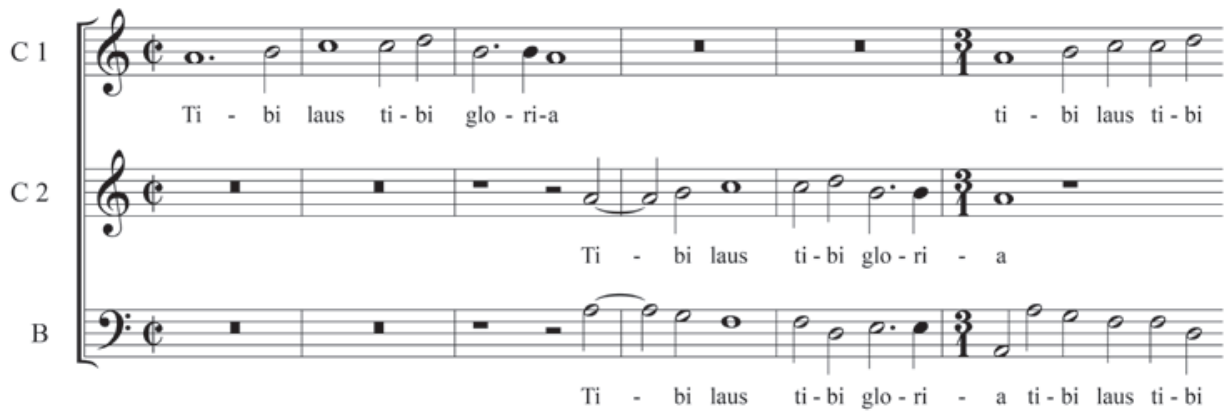




\section{Sources and Bibliography}

Archival Sources And Music Manuscripts

Berlin, Staatsbibliothek zu Berlin - Preußischer Kulturbesitz, Musikabteilung (D-B), Mus. ms. 40073.

Budapest, Országos Széchényi Könyvtár (H-Bn), 18/2f.

Cracow, Archiwum Narodowe, Oddział III: Acta Advocatialia Cracoviensis, 235.

Cracow, Biblioteka Jagiellońska (PL-Kj), Mus. ms. 40063.

Pelplin, Wyższe Seminarium Duchowne Diecezji Pelplińskiej, Biblioteka (PL-PE), Tabulatura Pelplińska [The Pelplin Tablature], Mus. ms. 304, 306/1, 307, 308.

Uppsala, Universitetsbibliotek, Carolina Rediviva (S-Uu), Utl. vok. mus. i tr. 394-399, RISM 190008600.

Vilnius, Lietuvos mokslų akademija Vrublevskių biblioteka (LT-Va), Mus. ms. 284.

Warsaw, Archiwum Główne Akt Dawnych: ASK I, 296, fol. 79r.

\section{EARLY PRINTS}

Cocciola, Giovanni Battista. Concentus harmonici ecclesiastici. Antwerp: Pierre Phalèse, 1625. RISM C 3251, CC 3251.

Bonometti, Giovanni Battista, ed. Parnassus musicus Ferdinandaeus. Venice: Giacomo Vincenti, 1615. RISM $1615^{13}$.

Donfrid, Johann, ed. Promptuarii musici, concentus ecclesiasticos [...] Pars III. Strasbourg: Paul Ledertz, 1627. RISM $1627^{1}$.

Vincenti, Alessandro. Indice di tutte le opere di musica che si trovano nella Stampa della Pigna. Venice: Alessandro Vincenti, 1619.

\section{LiteratURE}

Antonicek, Theophil, ed. Parnassus musicus Ferdinandeus herausgegeben von Giovanni Battista Bonometti (1615). Denkmäler der Tonkunst in Österreich, 159. Graz: Akademische Druck- u. Verlagsanstalt, 2015.

Bieńkowska, Irena. "Concerti Ecclesiastici by Giovanni Battista Cocciola in the Light of the Seconda Prattica". Inside the Music (online scientific platform). http://inmus.net/ wp-content/uploads/2014/07/Cocciola_Concerti-ecclesiastici_1_PL.pdf.

____ . "Muzyka Giovanniego Battisty Coccioli". 2 vols. PhD diss., Uniwersytet Warszawski, 1999.

___ . "Religious Works of Giovanni Battista Cocciola (16th/17th Century): The Topography of Sources". In Musical Culture of the Bohemian Lands and Central Europe before 1620, edited by Lenka Hlávková and Jiří K. Kroupa, 309-321. Prague: Konias Latin Press, 2011.

___ . "The Polychoral Works of G. B. Coccciola from the Pelplin Tabulature within the Context of the Stylistic Changes of the Epoch". In Musica Baltica, Im Umkreis des Wandels - von den cori spezzati zum konzertierenden Stil, edited by Janusz Krassowski et al., 45-60. Gdańsk: Akademia Muzyczna, 2004.

\footnotetext{
____ " "Ukształtowania drobnoodcinkowe w małogłosowych kompozycjach religijnych
} 
Giovanniego Battisty Coccioli”. In Complexus effectuum musicologiae studia Miroslao Perz septuagenario dedicata, edited by Tomasz Jeż, 373-383. Cracow: Rabid, 2003.

Cocciola, Giovanni Battista. Dzieła zebrane, edited by Irena Bieńkowska. Warsaw: BelStudio, 2004.

Gerber, Ernst Ludwig. Historisch-Biographisches Lexikon der Tonkünstler. Vol. 1. Leipzig: Breitkopf, 1790.

Göhler, Karl Albert. "Die Messkataloge im Dienste der musikalischen Geschichtsforschung". Sammelbände der Internationalen Musikgesellschaft 3, no. 2 (1902): 294-376.

Guillo, Laurent. "La bibliothèque de musique des Ballard d'après l'inventaire de 1750 et les notes de Sébastien de Brossard (Seconde partie)". Revue de musicologie 91, no. 1 (2005): 195-232. https://doi.org/10.2307/20141600.

Osostowicz-Sutkowska, Alina. “G. B. Cocciola e l'intavolatura di Pelplin”. Rivista Italiana di Musicologia 5 (1970): 61-72.

___ . "Twórczość Giovanniego Battisty Coccioli w świetle Tabulatury Pelplińskiej". Master's thesis, Uniwersytet Warszawski, 1963.

Patalas, Aleksandra. "Asprilio Pacelli in Poland: Compositions, Techniques, Reception". In Italian music in Central-Eastern Europe: Around Mikotaj Zieleński's "Offertoria" and "Communiones" (1611), edited by Tomasz Jeż, Barbara Przybyszewska-Jarmińska and Marina Toffetti, 235-260. Venice: Edizioni Fondazione Levi, 2015.

Praetorius, Michael. Syntagma Musicum. Vol. 3. Wolfenbüttel: Michael Praetorius, Elias Holwein, 1619.

Sutkowski, Adam, and Alina Osostowicz-Sutkowska, eds. The Pelplin Tablature. 10 vols. Graz: Akademische Druck- und Verlagsanstalt; Warsaw: Polish Scientific Publishers, 1963. 


\section{DELOVANJE GIOVANNIJA BATTISTE COCCIOLE V POLJSKO-LITOVSKI ZVEZI IN NJEGOV MOTET AVE MUNDI SPES MARIA IZ ZBIRKE PARNASSUS MUSICUS FERDINANDAEUS}

\section{Povzetek}

Giovanni Battista Cocciola se je rodil v italijanskem Vercelliju, a je deloval predvsem v Poljsko-litovski zvezi. Njegova glasbena zapuščina je v mednarodni muzikološki literaturi le malo znana. Z glasbo Cocciole sta se doslej ukvarjali predvsem Alina Osostowicz Sutkowska in Irena Bieńkowska. Cocciola bi lahko bil eden izmed italijanskih glasbenikov, ki so bili konec 16. stoletja zaposleni v dvorni glasbeni kapeli poljskega kralja Sigismunda III. Vase. Vsaj od leta 1606 je bil v službi škofa Szymona Rudnickija v Warmii (tedaj v kraljevi Prusiji). Zanimivo je, da je prav na začetku monumentalnega rokopisa z orgelskimi tabulaturami, ki je nastal med 1620 in 1640 v cistercijanskem samostanu v Pelplinu (tedaj prav tako v kraljevi Prusiji), zapisana skupina štirinajstih Cocciolovih cerkvenih skladb za dva do tri glasove. Tem so pozneje dodali še nekaj drugih njegovih kompozicij. Možno bi bilo, da so bile te skladbe prepisane iz pozneje izgubljene zbirke duhovnih koncertov, tiskane ali pa pripravljene za natis. Cocciola je v Gdansku tiskal danes izgubljeno zbirko kanconet, verjetno za dva in tri glasove, ki jo je imel krakovski knjigarnar na zalogi še leta 1613. Sklepali bi lahko, da se je prav s to izdajo začela Cocciolova skladateljska pot.

Vsaj od leta 1623 je bil Cocciola kapelnik na dvoru Leona Sapiehe (1557-1633), enega najpomembnejših politikov in diplomatov Poljsko-litovske zveze. O skladateljevi povezavi s Sapieho priča izdaja (verjetno prvi ponatis) njegove zbirke koncertantnih motetov Concentus Harmonici leta 1625. Zbirka vsebuje 20 skladb za nekaj glasov (enega do pet) in orgle. Cocciolov skladateljski opus sicer obsega štiri večje glasbene zvrsti: kanconete, večzborske motete, maše in male koncertantne motete, imenovane tudi cerkveni koncerti. Njegova glavna zvrst so bili concerti ecclesiastici za nekaj glasov, ki so bili za tedaj značilne glasbene skupine najbolj primerni. Ta tip skladbe je tudi motet Ave mundi spes Maria, ki je bil uvrščen tudi v antologijo Parnassus musicus Ferdinandaeus. Čeprav izrazna sredstva, ki jih je Cocciola uporabil v tej skladbi, niso med najnaprednejšimi, pričajo o njegovem poznavanju koncepta tedaj nove glasbe. In čeprav je bila evropska kariera tega skladatelja precej omejena, je odigral pomembno vlogo v procesu prenosa in udomačitve italijanskega cerkvenega koncerta na ozemlju Poljsko-litovske zveze. 